\title{
Athletic Training Student and Student Aide Clinical Task Allowance in the Secondary School Setting
}

\author{
Zachary K. Winkelmann \\ Indiana State University, winkelz@mailbox.sc.edu \\ Robert A. Huggins \\ University of Connecticut, robert.huggins@uconn.edu \\ Lindsey E. Eberman \\ Indiana State University, lindsey.eberman@indstate.edu
}

Follow this and additional works at: https://nsuworks.nova.edu/ijahsp

Part of the Other Educational Administration and Supervision Commons, and the Sports Medicine Commons

\section{Recommended Citation}

Winkelmann ZK, Huggins RA, Eberman LE. Athletic Training Student and Student Aide Clinical Task Allowance in the Secondary School Setting. The Internet Journal of Allied Health Sciences and Practice. 2019 Jan 01;17(3), Article 4.

This Manuscript is brought to you for free and open access by the College of Health Care Sciences at NSUWorks. It has been accepted for inclusion in Internet Journal of Allied Health Sciences and Practice by an authorized editor of NSUWorks. For more information, please contact nsuworks@nova.edu. 


\title{
Athletic Training Student and Student Aide Clinical Task Allowance in the Secondary School Setting
}

\begin{abstract}
Purpose: Athletic training student aides (SA) are minors in high school that participate in an athletic training experience under the supervision of secondary school athletic trainers (SSAT). The NATA published an official statement on the proper supervision of SAs related to task allowance. As SSATs may also supervise athletic training students (ATSs), it is important to understand the differences in both. Therefore, the objective was to explore the training, task allowance, and perspectives of SAs and ATSs by SSATs during clinical experiences. Methods: We used a cross-sectional, web-based survey for this study. SSATs $(n=3,567)$ from the ATLAS database were recruited and 614 participants (age $=39 \pm 11$ years, years credentialed $=12 \pm$ years) completed the study. An online survey was developed to reflect the NATA official statement for task allowance and supervision of SAs and ATSs. Dependent variables included requirements and task allowance of the SA and ATS based on supervision (direct, autonomous, and restricted), and the personal perceptions from SSATs. Results: $76.5 \%$ of SSATs reported having SAs involved in their clinical practice. Less than $50 \%$ of SSATs implemented recommended trainings related to emergency preparedness, first aid, and patient privacy. When exploring task allowance, most SSATs were following best practice guidelines for job-related tasks. Additionally, SSATs were allowing ATSs to perform more tasks autonomously as compared to SAs. Conclusions: SSATs are mostly following best practice recommendations for task allowance, whereby they are providing supervision to SAs in the appropriate areas and not allowing certain duties. However, $100 \%$ compliance was not met, thus increasing risks to patients and the profession. SSATs should improve training and preparedness for the SAs involved in their clinical practice Additionally, SSATs are allowing ATSs to perform job-related tasks autonomously or with directed supervision during clinical experiences with the exception to administrative tasks and autonomous clinical-decision making.
\end{abstract}

\section{Author Bio(s)}

Zachary K. Winkelmann, MS, LAT, ATC, is a PhD Candidate in Curriculum and Instruction at Indiana State University. He is also a licensed and certified athletic trainer serving as a doctoral fellow for the athletic training programs.

Robert A. Huggins, PhD, LAT, ATC, is an Assistant Research Professor, President of Research and Athlete Performance, and Director Athletic Training Locations and Services (ATLAS) Project for the Korey Stringer Institute at The University of Connecticut in Storrs, CT.

Lindsey E. Eberman, PhD, LAT, ATC, is a Professor at Indiana State University in the Department of Applied Medicine and Rehabilitation.She is currently the Program Director for the Post-Professional Doctorate in Athletic Training Program.

\section{Acknowledgements}

The authors wish to acknowledge the support of the Korey Stringer Institute's, Athletic Training Locations and Services (ATLAS) Project, at the University of Connecticut for this project. Conclusions drawn from or recommendations based on the data provided by the KSI are those of the author(s) and do not necessarily represent the official views of the KSI. 


\title{
IIAHSP ${ }^{\mathrm{m}}$ \\ The Internet Journal of Allied Health Sciences and Practice \\ Dedicated to allied health professional practice and education
}

Vol. 17 No. 3 ISSN 1540-580X

\section{Athletic Training Student and Student Aide Clinical Task Allowance in the Secondary School Setting}

\author{
Zachary K. Winkelmann ${ }^{1}$ \\ Robert A. Huggins ${ }^{2}$ \\ Lindsey E. Eberman ${ }^{1}$ \\ 1. Indiana State University \\ 2. University of Connecticut \\ United States
}

\begin{abstract}
Purpose: Athletic training student aides $(\mathrm{SA})$ are minors in high school that participate in an athletic training experience under the supervision of secondary school athletic trainers (SSAT). The NATA published an official statement on the proper supervision of SAs related to task allowance. As SSATs may also supervise athletic training students (ATSs), it is important to understand the differences in both. Therefore, the objective was to explore the training, task allowance, and perspectives of SAs and ATSs by SSATs during clinical experiences. Methods: We used a cross-sectional, web-based survey for this study. SSATs $(n=3,567)$ from the ATLAS database were recruited, and 614 participants (age $=39 \pm 11$ years, years credentialed $=12 \pm 9 y e a r s$ ) completed the study. An online survey was developed to reflect the NATA official statement for task allowance and supervision of SAs and ATSs. Dependent variables included requirements and task allowance of the SA and ATS based on supervision (direct, autonomous, and restricted), and the personal perceptions from SSATs. Results: $76.5 \%$ of SSATs reported having SAs involved in their clinical practice. Less than $50 \%$ of SSATs implemented recommended trainings related to emergency preparedness, first aid, and patient privacy. When exploring task allowance, most SSATs were following best practice guidelines for job-related tasks. Additionally, SSATs were allowing ATSs to perform more tasks autonomously as compared to SAs. Conclusions: SSATs are mostly following best practice recommendations for task allowance, whereby they are providing supervision to SAs in the appropriate areas and not allowing certain duties. However, $100 \%$ compliance was not met, thus increasing risks to patients and the profession. SSATs should improve training and preparedness for the SAs involved in their clinical practice Additionally, SSATs are allowing ATSs to perform job-related tasks autonomously or with directed supervision during clinical experiences with the exception of administrative tasks and autonomous clinical-decision making.
\end{abstract}

Keywords: high school, risk management, professional issues, clinical education 


\section{INTRODUCTION}

Over the past decade, the expansion of athletic training services in the secondary school setting has improved the access to patient care for millions of student-athletes. ${ }^{1,2}$ The athletic trainers working in the secondary school setting serve as one of the only primary healthcare providers, alongside secondary school nurses, for these educational campuses. ${ }^{3}$ In addition, the secondary school athletic trainer (SSAT) often experiences a high provider to patient ratio with previous research identifying that most of these individuals are the sole athletic trainer for all student-athletes at the school. 4,5 When further examining the patient load for secondary schools with athletic training services, previous research identified an average of 432 student-athletes in the public school setting and 268 student-athletes in the private school setting. 2,6 The potential number of patients for the SSAT has led to a role strain as a result of long work hours and understaffing. 7,8 Nevertheless, the secondary school setting affords many opportunities for the athletic trainer to create and foster relationships for their patients, parents, and school officials alike that have resulted in high job satisfaction. 4,9

While the primary job description for many athletic trainers is to provide healthcare services, the SSAT may have additional teaching responsibilities at the secondary school because of the structure of human resources for many school districts. ${ }^{10,11}$ For those who have additional teaching responsibilities, the SSAT will typically teach a sports medicine, health or physical education, and/or a first aid course to the secondary school students. The course itself exposes the secondary school student to the field of medicine and the specialty of sports medicine. Outside of the formal course load that may be required to be facilitated at the school, SSATs may also serve as a liaison or coordinator of before, during, or after school extra-curricular activities. While this additional role may include a variety of clubs and organizations, one method SSATs serve in this leadership capacity is to incorporate the secondary school students into their athletic training facility to allow an opportunity for job shadowing of work experiences. These individuals, student aides (SAs), are secondary school students between 12-18 years old, most often considered minors in each state, that participate in an athletic training experience at their secondary school typically under the supervision of the SSAT.12,13 The SAs are prohibited from participating in some of the duties of a credentialed athletic trainer. ${ }^{13}$ At the same time, the SSAT may also serve as a formal clinical teacher, known as a preceptor, for an accredited athletic training program.

In this role as a preceptor, the SSAT teaches and evaluates college/university students referred to as athletic training students (ATS), which is a student enrolled in a CAATE accredited professional athletic training program, for a period to learn and provide actual patient care. The ATSs are required to complete a "progression of increasingly complex and autonomous patient-care and client-care experiences" through "clinical practice opportunities....with real client/patients in settings where athletic trainers commonly practice." 14 As a result, the SA (minor; secondary school student) and ATS (adult; college/university student) have different requirements and expectations during their time spent under the supervision of the SSAT. Because of the potential misinterpretation between the students, the National Athletic Trainers' Association (NATA) has published three resource documents related to SAs. 13,15,16 The Official Statement on Proper Supervision of Secondary School Student Aides, the Secondary School Student Aide Q\&A, and the Student Aide Response Letter each seek to provide regulation expectations as it relates to SAs in athletic training facilities.

The relationship between the preceptor and ATS is formally supervised by the athletic training program that is regulated by the Commission on Accreditation of Athletic Training Education (CAATE). CAATE protects the role and tasks of each party as it relates to direct supervision of ATS task performance. ${ }^{14}$ Direct supervision, as defined by the CAATE in the 2012 standards, is being physically present with the ability to intervene on behalf of the student and the patient. ${ }^{17}$ Updated in the 2020 CAATE standards, supervision is described as a continual process "that allows a student to move from interdependence to independence based on the student's knowledge and skills as well as the context of care," while still being "on-site and [with] the ability to intervene on behalf of the athletic training student and the patient."14 Interestingly, the formal regulation and quality assurance checks for an ATS in contrast to the lack of professional accountability for an SA may create discord and confusion about the tasks allowed, regardless of age, training, and formal education related to athletic training. In addition, the public image may suggest there is an interchangeability between SAs, ATSs, and SSATs, which may compromise our professional identity. In addition, there may be a potential risk to a patient's safety during clinical care if they are receiving recommendations and interventions from an untrained minor compared to a supervised student in training versus a credentialed healthcare provider. As a result, there is a need delineate the distinct differences between SAs and ATSs task allowance during clinical experiences.

From the resource documents on SA supervision, several daily tasks of athletic training clinical practice are identified in terms of what may or may not be performed. The NATA states that "student aides must only observe the licensed/certified trainer outside of the educational environment."13 The NATA has clearly delineated that an SA should not interpret referrals, perform evaluations, make intervention decisions, plan patient care, or independently travel to provide patient care for athletic teams. ${ }^{13}$ Contrastingly, an ATS should be able to perform all of the previously mentioned tasks, minus independent travel, as part of their clinical experience 
with proper supervision. The justification for these differences is linked to the educational preparation of an ATS, whereby the athletic training program has a requirement to "determine that students are ready to engage in clinical experiences and are competent and safe to perform skills on a client/patient population."14

Although there are challenges when SAs are within an athletic training facility, there are even more concerns when both SAs and ATSs are concurrently present in the same facility, specifically as it relates to delineating tasks. As such, there is a need to examine the task allowance of SAs and ATSs relative to supervision, training, and rationale during clinical experiences from the lens of the SSAT. The significance of this project is its assessment of the risk mitigation behaviors of SSATs related to the NATA advisory documents associated with having SAs and ATSs participating in clinical learning activities within their athletic training facilities. Specifically, we aimed to explore three objectives:

1. To examine the background and duties of the SSATs that serve as a CAATE preceptor and/or support of a high school athletic training experience.

2. To examine the requirements of(risk management trainings, terminology of students, dress code for students and feelings about SAs and ATSs in the secondary school setting.

3. To examine the tasks SAs and ATSs completing clinical rotations are allowed to perform relative to the NATA resource guide for secondary school athletic trainers.

\section{METHODS \\ Design}

This study used a cross-sectional design with a web-based survey to explore the task allowance of SAs and ATSs as self-reported by SSATs. This study was deemed to be exempt research by the Institutional Review Board.

\section{Respondents}

We recruited a national sample of prospective subjects $(n=3,567)$ that identified as a SSAT through the Korey Stringer Institute's Athletic Training Locations and Services (ATLAS) Database. ${ }^{18}$ A total of 819 individuals started the survey $(23 \%$ survey access rate) with 614 participants (age $=39 \pm 11$ years, years credentialed $=12 \pm 9$ years) classified as complete responders or item nonresponders that were included in the analysis ( $75 \%$ survey completion rate). ${ }^{19}$ Demographic data including the school type (public vs. private), teaching responsibilities, state of practice, and number of SSATs at the school were collected and matched for each participant from the ATLAS Database (2016 version). Most participants worked in a public secondary school $(n=490 / 614,79.8 \%)$, and were from Texas $(n=83 / 614,13.5 \%)$, Pennsylvania $(n=31 / 614,5.0 \%)$, and South Carolina $(n=31 / 614,5.0 \%)$. Most of the participants did not have teaching responsibilities $(n=361 / 614,58.8 \%)$ and worked as the only SSAT $(n=362 / 614,59.0 \%)$ at their secondary school.

\section{Instrumentation}

A web-based survey was developed to reflect the NATA official statements for task allowance and supervision of SAs. ${ }^{13}$ The survey was pilot tested for face validity by three practicing SSATs (one AT with SAs, one AT with ATSs, and one AT with neither), prior to distribution with no major changes to the instrument. ${ }^{20}$ Because of the demographic nature of the survey items, other assessments of validity and reliability were not warranted. The survey contained two personal background questions followed by two additional sections relative to what level of students (SAs and/or ATSs) are completing clinical experiences within their athletic training facility. The items for each section were displayed if the participant identified that they currently integrated either of these student populations in their clinical practice. The questions per student group were the same focusing on number of students ( 2 questions), trainings and requirements (8 questions), tasks allowance (24 questions), and perceptions of supervising the students from the athletic trainer's point of view (1 question). In the task allowance section of the survey, the participant was presented with a list of clinical tasks (e.g. - interpret referrals from other healthcare providers) and asked to identify if they allowed the SA or ATS to perform the task 1) autonomously, 2) with direct supervision, 3) with both direct and indirect supervision, or 4) not allowed to perform the task. An operational definition of direct and indirect supervision were provided to the participants in the survey. Following data collection but prior to analysis, seven practicing SSATs that did not participate in this study classified each of the 24 tasks either as a low, moderate, or a high-risk activity using consensus agreement by the research team. ${ }^{20}$ Risk was operationally defined for the consensus panel as "exposing danger to patients or themselves if completed autonomously." Finally, the participants that neither integrated SAs or ATSs in their clinical practice received two questions related to their reasoning on why they opted to not partake in this role as a clinical teacher.

\section{Procedures}

In mid-October of 2017, a recruitment e-mail was sent to all registered SSATs in the ATLAS Database that a contained a URL for the confidential study that was hosted on a web-based platform (Qualtrics ${ }^{\circledR}$ Inc., Provo, UT). The participants indicated consent and then entered the tool with display logic related to their role as having SAs, ATSs, both, or neither in their athletic training facility. 
The study remained open for one month with reminder e-mails sent each week to improve the response rate. Participants were able to skip any question that they wished to ensure voluntariness.

\section{Data Analysis}

Data from the survey were analyzed using Microsoft ${ }^{\circledR}$ Excel 2016. We calculated descriptive statistics (frequencies, means, and standard deviations) for each survey item, as well as separated by the participant serving as a clinical teacher for either SAs, ATSs, both, or neither for follow-up comparisons. Item non-responders were included for all analyses whereby they viewed the entire survey but only partially completed all questions, while partial data collected from answering drop-outs were excluded as they quit prior to completing the instrument (final question not displayed). ${ }^{19}$

\section{RESULTS}

Most participants stated they only supervised SAs ( $n=302 / 614,49.2 \%$ ), while $27.3 \%$ supervised both SAs and ATS ( $n=168 / 614)$ and even less only supervised ATS ( $n=66 / 614,10.7 \%)$. Twelve-percent $(n=78 / 614)$ of the participants stated they had neither SAs nor ATSs involved with their daily athletic training clinical practice. From the total sample, $76.5 \%$ of participants $(n=470 / 614)$ stated their secondary school allowed an SA program in some capacity (before, during, or after school).

\section{Student Aides}

For those SSATs that supervised SAs, they averaged $13 \pm 25$ SAs per year with $6 \pm 16$ SAs per day involved in their clinical practice. The majority of the participants did not use the correct terminology when referring to the secondary school student as a $\mathrm{SA}(\mathrm{n}=301 / 470,64 \%)$ with most of the participants identifying they use the term "student athletic trainer" $(\mathrm{n}=118 / 301,39.2 \%)$ when referring to high school students involved in their clinical practice. Only $20.9 \%$ of participants $(n=98 / 470)$ provided clothes or attire for the SAs that were a different color from the certified athletic trainer (best practice guideline), but $38.1 \%$ of participants $(n=179 / 470)$ stated they had a dress code without providing clothes or attire for the SA.

With regard to training and preparedness of SAs, we categorized the participant as either meeting all recommended trainings for SAs ( $n=72 / 468,15.4 \%)$, meets some (1-3) of the recommended trainings for SAs ( $n=226 / 468,48.3 \%)$, or did not meet any of the recommended trainings for SAs $(n=170 / 468,36.3 \%)$. Table 1 contains the frequency breakdown for each training module recommended for SAs. Additionally, most participants $(n=217 / 470,46.2 \%)$ stated that the SAs do not practice the emergency action plans and are not included as part of the emergency personnel team in the document.

Table 1. Frequency of Recommended Trainings for SAs as reported by the SSAT ( $n=470)$

\begin{tabular}{lcccc}
\hline & CPR/AED & First Aid & HIPAA and FERPA & Blood-borne pathogen \\
\hline Required & $223,47.4 \%$ & $213,45.3 \%$ & $144,30.6 \%$ & $169,36.0 \%$ \\
Not Required & $229,48.7 \%$ & $238,50.6 \%$ & $301,64.0 \%$ & $275,58.5 \%$ \\
Unsure & $16,3.4 \%$ & $16,3.4 \%$ & $22,4.7 \%$ & $22,4.7 \%$ \\
Missing & $2,0.4 \%$ & $3,0.6 \%$ & $3,0.6 \%$ & $4,0.9 \%$ \\
\hline
\end{tabular}

Table 2 depicts the task allowance reported by the SSAT. The respondents reported either allowing the SA to complete the tasks with either autonomous, direct supervision only, indirect and direct supervision, or not permitted to perform. We identified that while $100 \%$ compliance is not being met, the majority of SSATs are providing proper supervision and task allowance of the SAs. Specific notable findings include that $63.8 \%$ of SSATs report travel to away games is only permitted with direct supervision; while over $90 \%$ respondents stated that SAs are not allowed to interpret referrals from other healthcare providers or give a student-athlete over the counter medication. The task with the worst adherence to official statements from the NATA was the allowance of SAs to tape non-injured athletes for preventative measures prior to or during athletic activity with only 180 of the SSATs (38.3\%) stating they followed best practice recommendations to not allow SAs to complete this task. The frequency of each task as it relates to the supervisory status of the SSAT for the SA as is presented in Table 2. 
Table 2. Task Allowance Reported by the SSAT. Participants responded whether the SA could perform the task based on the headings. Data includes the frequency of task allowance. Bold data are the correct choice based on best practice recommendations. $(n=470)$

\begin{tabular}{|c|c|c|c|c|c|}
\hline Task & Autonomous & $\begin{array}{l}\text { Only with Direct } \\
\text { Supervision }\end{array}$ & $\begin{array}{c}\text { Direct + } \\
\text { Indirect } \\
\text { Supervision }\end{array}$ & $\begin{array}{l}\text { Not Permitted to } \\
\text { Perform }\end{array}$ & Missing \\
\hline $\begin{array}{l}\text { Set up and break down of sideline } \\
\text { equipment }\end{array}$ & $385,81.9 \%$ & $60,12.8 \%$ & $11,2.3 \%$ & $11,2.3 \%$ & $3,0.6 \%$ \\
\hline $\begin{array}{l}\text { Perform a concussion evaluation } \\
\text { for an athlete }\end{array}$ & $0,0 \%$ & $28,6.0 \%$ & $0,0 \%$ & $439,93.4 \%$ & $3,0.6 \%$ \\
\hline $\begin{array}{l}\text { Recognize an athlete with heat } \\
\text { illness (signs/symptoms) }\end{array}$ & $55,11.7 \%$ & $191,40.6 \%$ & $10,2.1 \%$ & $205,43.6 \%$ & $9,1.9 \%$ \\
\hline $\begin{array}{l}\text { Perform an orthopedic evaluation } \\
\text { of an injured athlete }\end{array}$ & $1,0.2 \%$ & $54,11.5 \%$ & $0,0 \%$ & $405,86.2 \%$ & $10,2.1 \%$ \\
\hline Make and apply ice bags & $223,47.4 \%$ & $201,42.8 \%$ & $18,3.8 \%$ & $26,5.5 \%$ & $2,0.4 \%$ \\
\hline $\begin{array}{l}\text { Tape non-injured athletes for } \\
\text { preventative measures prior } \\
\text { to or during athletic activity }\end{array}$ & $65,13.8 \%$ & $208,44.3 \%$ & $10,2.1 \%$ & $180,38.3 \%$ & $7,1.5 \%$ \\
\hline $\begin{array}{l}\text { Practice taping on other student } \\
\text { aides }\end{array}$ & $187,39.8 \%$ & $225,47.9 \%$ & $30,6.4 \%$ & $27,5.7 \%$ & $1,0.2 \%$ \\
\hline Hydration specialization & $202,43.0 \%$ & $156,33.2 \%$ & $17,3.6 \%$ & $86,18.3 \%$ & $9,1.9 \%$ \\
\hline $\begin{array}{l}\text { Clear an athlete to return to the } \\
\text { game after being hurt }\end{array}$ & $0,0 \%$ & $2,0.4 \%$ & $0,0 \%$ & $465,98.9 \%$ & $3,0.6 \%$ \\
\hline Tape an injured athlete's ankle & $14,3.0 \%$ & $130,27.7 \%$ & $6,1.3 \%$ & $311,66.2 \%$ & $9,1.9 \%$ \\
\hline $\begin{array}{l}\text { Make up rehabilitation exercises } \\
\text { for an injured athlete }\end{array}$ & $0,0 \%$ & $111,23.6 \%$ & $1,0.2 \%$ & $348,74.3 \%$ & $9,1.9 \%$ \\
\hline Travel to away games & $60,12.8 \%$ & $300,63.8 \%$ & $8,1.7 \%$ & $94,20.0 \%$ & $8,1.7 \%$ \\
\hline $\begin{array}{l}\text { Stocking kits, taping tables, } \\
\text { shelves, etc. }\end{array}$ & $285,60.6 \%$ & $123,26.2 \%$ & $32,6.8 \%$ & $26,5.5 \%$ & $4,0.9 \%$ \\
\hline $\begin{array}{l}\text { Give a student-athlete over the } \\
\text { counter (OTC) medicine }\end{array}$ & $2,0.4 \%$ & $21,4.5 \%$ & $0,0 \%$ & $443,94.3 \%$ & $4,0.9 \%$ \\
\hline $\begin{array}{l}\text { Serve as "eyes and ears" at an } \\
\text { athletic event using a walkie- } \\
\text { talkie to communicate to the } \\
\text { ATC located elsewhere }\end{array}$ & $157,33.4 \%$ & $85,18.1 \%$ & $14,3.0 \%$ & $208,44.3 \%$ & $6,1.3 \%$ \\
\hline File patient records & $62,13.2 \%$ & $156,33.2 \%$ & $4,0.9 \%$ & $240,51.1 \%$ & $8,1.7 \%$ \\
\hline $\begin{array}{l}\text { Perform e-stim or ultrasound on } \\
\text { an athlete }\end{array}$ & $2,0.4 \%$ & $90,19.2 \%$ & $1,0.2 \%$ & $370,78.7 \%$ & $7,1.5 \%$ \\
\hline $\begin{array}{l}\text { Perform wound care (bandages, } \\
\text { stopping blood, etc.) }\end{array}$ & $103,21.9 \%$ & $248,52.8 \%$ & $25,5.3 \%$ & $90,19.2 \%$ & $4,0.9 \%$ \\
\hline Stretching players & $83,17.7 \%$ & $277,58.9 \%$ & $19,4.0 \%$ & $83,17.4 \%$ & $8,1.7 \%$ \\
\hline $\begin{array}{l}\text { Talk to parents of an injured } \\
\text { athlete } \\
\text { about their child's injury }\end{array}$ & $0,0 \%$ & $5,1.1 \%$ & $0,0 \%$ & $462,98.3 \%$ & $3,0.6 \%$ \\
\hline $\begin{array}{l}\text { Interpret referrals from other } \\
\text { healthcare providers }\end{array}$ & $0,0 \%$ & $8,1.7 \%$ & $0,0 \%$ & $459,97.7 \%$ & $3,0.6 \%$ \\
\hline $\begin{array}{l}\text { Enforcing athlete sign-in } \\
\text { procedures }\end{array}$ & $219,46.6 \%$ & $157,32.1 \%$ & $32,6.8 \%$ & $63,13.4 \%$ & $5,1.1 \%$ \\
\hline $\begin{array}{l}\text { Enter injury data into an EMR } \\
\text { system }\end{array}$ & $19,4.0 \%$ & $98,20.9 \%$ & $9,1.9 \%$ & $337,71.7 \%$ & $7,1.5 \%$ \\
\hline
\end{tabular}


Finally, the perspectives of the participants with SAs at their clinical site mostly agreed that having the SA involved with the athletic training experience at the secondary school allowed the SSAT to teach and mentor about athletic training $(n=423 / 470,90 \%)$ and allowed the secondary school students to get hands on experience $(n=339 / 470,72.1 \%)$. Contrastingly, only a small percentage of the participants felt having SAs was an extensive time-demand and stressor of the job $(n=53 / 470,11.3 \%)$ or that their presence devalued the role of a SSAT ( $n=17 / 470,3.6 \%)$. For the participants who completed the instrument, but did not supervise SAs $(n=144 / 614,23.5 \%)$, most identified either the time to supervise the $S A(n=57 / 144,39.6 \%)$ or legal, ethical and regulatory principles $(n=41 / 144,28.5 \%)$ as the rationale for not involving SAs in their athletic training facility, yet agreed with those who do serve in this supervisory capacity that it would allow them the opportunity to teach and mentor about athletic training ( $n=117 / 144,81.3 \%)$.

\section{Athletic Training Students}

When exploring the completed instruments, $38.1 \%$ of the participants $(n=234 / 614)$ stated they served a preceptor for a CAATE accredited athletic training program as compared to the $76.5 \%(n=470 / 614)$ of participants that who supervised SAs. This sample reporting to be CAATE preceptors self-reported having $3 \pm 2$ ATS per year with $1 \pm 1$ ATS per day. In terms of dress code, participants mostly stated they either did not provide clothes, but enforced a dress code ( $n=131 / 234,56.0 \%$ ) or they provided clothes that matched the certified athletic trainer $(n=84 / 234,35.9 \%)$. As training and preparedness is not a requirement of the clinical site but of the athletic training program, the SSATs were not asked about CPR/AED, first aid, HIPAA/FERPA, or bloodborne pathogen training of the ATS. Most participants stated the ATSs practice the emergency action plans, but are not listed as part of the emergency personnel team in the document $(n=127 / 234,54.3 \%)$. Interestingly, $21.8 \%(n=51 / 234)$ of the participants stated they do not practice their emergency action plan(s) at the secondary school.

While the CAATE regulates tasks using supervisory terms, they do not list specific tasks that an ATS cannot perform. This is because all tasks of the job should be allowed for the student to complete in some nature during their clinical experiences. As such, the accreditor and athletic training program allow for most of the tasks in this study to be performed by an ATS either with some type of supervision or autonomously dependent upon the level of knowledge and training of the student. The frequency of each task as it relates to the supervisory status of the SSATs for the ATS as either autonomous, direct supervision only, indirect and direct supervision, or not permitted to perform is presented in Table 3. Notable findings from these questions include the tasks that the participants stated they are not allowing to be performed that should be allowed under direct supervision which include filing patient record $(n=29,12.4 \%)$, performing therapeutic modalities $(n=32,13.7 \%)$, entering injury data into an electronic medical record $(n=35,14.9 \%)$, interpreting referrals from other healthcare providers $(n=84,35.9 \%)$, talking to the parents of an injured athlete about their child's injury $(n=87,37.2 \%)$, clearing an athlete to return to the game after being hurt $(n=122,52.1 \%)$, and giving a student-athlete over the counter medication $(n=208,88.9 \%)$. By way of contrast, $50 \%(n=119)$ of SSATs are permitting ATS to serve as the "eyes and ears" at an athletic event using a walkie-talkie to communicate to the certified athletic trainer located elsewhere.

Table 3. Task Allowance Reported by the SSAT for the ATS. Participants responded whether the ATS could perform the task based on the headings. Data includes the frequency of task allowance. Bold data are the correct choice per the CAATE standards for clinical education. $(n=234)$

\begin{tabular}{|c|c|c|c|c|c|}
\hline Task & Autonomous & $\begin{array}{l}\text { Only with Direct } \\
\text { Supervision }\end{array}$ & $\begin{array}{c}\text { Direct + } \\
\text { Indirect } \\
\text { Supervision }\end{array}$ & $\begin{array}{l}\text { Not Permitted to } \\
\text { Perform }\end{array}$ & Missing \\
\hline $\begin{array}{l}\text { Set up and break down of sideline } \\
\text { equipment }\end{array}$ & $201,85.9 \%$ & $23,9.8 \%$ & $7,3.0 \%$ & $2,0.9 \%$ & $1,0.4 \%$ \\
\hline $\begin{array}{l}\text { Perform a concussion evaluation for } \\
\text { an athlete }\end{array}$ & $6,2.6 \%$ & $196,83.8 \%$ & $2,0.9 \%$ & $24,10.2 \%$ & $6,2.6 \%$ \\
\hline $\begin{array}{l}\text { Recognize an athlete with heat } \\
\text { illness (signs/symptoms) }\end{array}$ & $41,17.5 \%$ & $172,73.5 \%$ & $17,7.3 \%$ & $1,0.4 \%$ & $3,1.3 \%$ \\
\hline $\begin{array}{l}\text { Perform an orthopedic evaluation of } \\
\text { an injured athlete }\end{array}$ & $9,3.8 \%$ & $207,88.4 \%$ & $9,3.8 \%$ & $3,1.3 \%$ & $5,2.1 \%$ \\
\hline Make and apply ice bags & $154,65.8 \%$ & $62,26.5 \%$ & $16,6.8 \%$ & $1,0.4 \%$ & $1,0.4 \%$ \\
\hline $\begin{array}{l}\text { Tape non-injured athletes for } \\
\text { preventative measures prior to } \\
\text { or during athletic activity }\end{array}$ & $82,35.0 \%$ & $128,54.7 \%$ & $15,6.4 \%$ & $6,2.6 \%$ & $3,1.3 \%$ \\
\hline $\begin{array}{l}\text { Practice taping on other athletic } \\
\text { training students }\end{array}$ & $164,70.1 \%$ & $50,21.4 \%$ & $18,7.7 \%$ & $1,0.4 \%$ & $1,0.4 \%$ \\
\hline Hydration specialization & $128,54.7 \%$ & $69,29.5 \%$ & $15,6.4 \%$ & $18,7.7 \%$ & $3,1.3 \%$ \\
\hline
\end{tabular}




\begin{tabular}{|c|c|c|c|c|c|}
\hline $\begin{array}{l}\text { Clear an athlete to return to the } \\
\text { game after being hurt }\end{array}$ & $2,0.9 \%$ & $104,44.4 \%$ & $0,0 \%$ & $122,52.1 \%$ & $6,2.6 \%$ \\
\hline Tape an injured athlete's ankle & $161,68.8 \%$ & $48,20.5 \%$ & $17,7.3 \%$ & $6,2.6 \%$ & $2,0.9 \%$ \\
\hline $\begin{array}{l}\text { Make up rehabilitation exercises for } \\
\text { an injured athlete }\end{array}$ & $50,21.4 \%$ & $168,71.8 \%$ & $8,3.4 \%$ & $6,2.6 \%$ & $2,0.9 \%$ \\
\hline Travel to away games & $5,2.1 \%$ & $181,77.4 \%$ & $41,17.5 \%$ & $2,0.9 \%$ & $5,2.1 \%$ \\
\hline $\begin{array}{l}\text { Stocking kits, taping tables, shelves, } \\
\text { etc. }\end{array}$ & $179,76.5 \%$ & $33,14.1 \%$ & $17,7.3 \%$ & $4,1.7 \%$ & $1,0.4 \%$ \\
\hline $\begin{array}{l}\text { Give a student-athlete over the } \\
\text { counter (OTC) medicine }\end{array}$ & $2,0.9 \%$ & $23,9.8 \%$ & $0,0.0 \%$ & $208,88.9 \%$ & $1,0.4 \%$ \\
\hline $\begin{array}{l}\text { Serve as "eyes and ears" at an } \\
\text { athletic event using a walkie-talkie } \\
\text { to communicate to the ATC } \\
\text { located elsewhere }\end{array}$ & $49,20.9 \%$ & $62,27.4 \%$ & $8,3.4 \%$ & $108,46.2 \%$ & $7,3.0 \%$ \\
\hline File patient records & $98,41.9 \%$ & $94,40.2 \%$ & $10,4.3 \%$ & $29,12.4 \%$ & $2,0.9 \%$ \\
\hline $\begin{array}{l}\text { Perform e-stim or ultrasound on an } \\
\text { athlete }\end{array}$ & $15,6.4 \%$ & $183,78.2 \%$ & $3,1.3 \%$ & $32,13.7 \%$ & $1,0.4 \%$ \\
\hline $\begin{array}{l}\text { Perform wound care (bandages, } \\
\text { stopping blood, etc.) }\end{array}$ & $89,38.0 \%$ & $130,55.6 \%$ & $13,5.6 \%$ & $1,0.4 \%$ & $1,0.4 \%$ \\
\hline Stretching players & $91,38.9 \%$ & $126,53.8 \%$ & $15,6.4 \%$ & $0,0 \%$ & $2,0.9 \%$ \\
\hline $\begin{array}{l}\text { Talk to parents of an injured athlete } \\
\text { about their child's injury }\end{array}$ & $2,0.9 \%$ & $134,57.3 \%$ & $2,0.9 \%$ & $87,37.2 \%$ & $9,3.8 \%$ \\
\hline $\begin{array}{l}\text { Interpret referrals from other } \\
\text { healthcare providers }\end{array}$ & $5,2.1 \%$ & $141,60.3 \%$ & $1,0.4 \%$ & $84,35.9 \%$ & $3,1.3 \%$ \\
\hline Enforcing athlete sign-in procedures & $143,61.1 \%$ & $65,27.8 \%$ & $20,8.5 \%$ & $4,1.7 \%$ & $2,0.9 \%$ \\
\hline $\begin{array}{l}\text { Enter injury data into an EMR } \\
\text { system }\end{array}$ & $59,25.2 \%$ & $124,53.0 \%$ & $14,6.0 \%$ & $35,14.9 \%$ & $2,0.9 \%$ \\
\hline
\end{tabular}

Participants with ATSs at their clinical site mostly agreed that having the ATS involved with the athletic training experience at the secondary school allowed the SSAT to teach and mentor about athletic training $(n=224 / 234,95.7 \%)$ and promoted the secondary school employment setting to the ATS ( $n=207 / 234,88.5 \%$ ). Additionally, several participants $(n=149 / 234,63.7 \%$ ) stated having an ATS allowed them more time to work with the patients. For the participants that identified as not serving as a CAATE preceptor in the secondary school setting $(n=380 / 614,61.9 \%)$, we were able to identify that most cited the rationale for not serving in this capacity was either no CAATE accredited athletic training program nearby their secondary school $(n=223)$ or having never been solicited/asked to be a preceptor $(n=48)$.

\section{Comparison of SA and ATSA Task Allowance}

When comparing the task allowance of those who supervised both SAs and ATSs ( $n=168 / 614,27.3 \%)$, we are able to identify that the SSAT is typically allowing the ATS to perform more tasks as compared to the SA. When exploring the frequency of autonomous task allowance by risk activities, we are able to determine that autonomous practice for ATSs and SAs is typically for low risk activities, such as setting up the field and stocking kits, while less frequent for high risk activities, such as talking to parents and clearing an athlete to return-to-play. Table 4 shows the comparison between task allowances by supervisory responsibility factor. 
Table 4. Task Allowance by Risk Category for those who supervise both SAs and ATSs $(n=168)$. Risk categories are colorcoded by high risk (red), moderate risk (yellow), and low risk (green).

\begin{tabular}{|c|c|c|c|c|}
\hline \multirow{2}{*}{$\begin{array}{l}\text { Task Allowance for SSATs with both } \\
\text { SAs and ATSs }(n=168)\end{array}$} & \multicolumn{2}{|c|}{ Autonomously Perform } & \multicolumn{2}{|c|}{$\begin{array}{l}\text { Not Permitted to Perform } \\
\text { Regardless of Supervision }\end{array}$} \\
\hline & $\begin{array}{l}\text { Student } \\
\text { Aides }\end{array}$ & $\begin{array}{l}\text { Athletic } \\
\text { Training } \\
\text { Student }\end{array}$ & $\begin{array}{l}\text { Student } \\
\text { Aides }\end{array}$ & $\begin{array}{l}\text { Athletic } \\
\text { Training } \\
\text { Student }\end{array}$ \\
\hline $\begin{array}{l}\text { Set up and break down of sideline } \\
\text { equipment }\end{array}$ & $137,79.7 \%$ & $151,87.3 \%$ & $6,3.5 \%$ & $2,1.2 \%$ \\
\hline $\begin{array}{l}\text { Perform a concussion evaluation for } \\
\text { an athlete }\end{array}$ & $0,0 \%$ & $5,2.9 \%$ & $163,96.5 \%$ & $18,10.4 \%$ \\
\hline $\begin{array}{l}\text { Recognize an athlete with heat } \\
\text { illness (signs/symptoms) }\end{array}$ & $22,12.6 \%$ & $45,24.6 \%$ & $87,50.0 \%$ & $2,1.2 \%$ \\
\hline $\begin{array}{l}\text { Perform an orthopedic evaluation of } \\
\text { an injured athlete }\end{array}$ & $0,0 \%$ & $12,6.8 \%$ & $156,92.3 \%$ & $4,2.3 \%$ \\
\hline Make and apply ice bags & $78,44.6 \%$ & $128,71.5 \%$ & $16,9.1 \%$ & $0,0 \%$ \\
\hline $\begin{array}{l}\text { Tape non-injured athletes for } \\
\text { preventative measures prior to } \\
\text { or during athletic activity }\end{array}$ & $17,9.9 \%$ & $73,40.3 \%$ & $80,46.5 \%$ & $5,2.8 \%$ \\
\hline Practice taping on other students & $74,40.9 \%$ & $134,72.4 \%$ & $10,5.5 \%$ & $0,0 \%$ \\
\hline Hydration specialization & $81,46.0 \%$ & $110,61.8 \%$ & $27,15.3 \%$ & $10,5.6 \%$ \\
\hline $\begin{array}{l}\text { Clear an athlete to return to the } \\
\text { game after being hurt }\end{array}$ & $0,0 \%$ & $2,1.2 \%$ & $167,99.4 \%$ & $83,48.5 \%$ \\
\hline Tape an injured athlete's ankle & $5,2.9 \%$ & $43,24.6 \%$ & $126,73.7 \%$ & $4,2.3 \%$ \\
\hline $\begin{array}{l}\text { Make up rehabilitation exercises for } \\
\text { an injured athlete }\end{array}$ & $0,0 \%$ & $17,9.7 \%$ & $145,84.3 \%$ & $4,2.3 \%$ \\
\hline Travel to away games & $25,14.5 \%$ & $6,3.5 \%$ & $38,22.0 \%$ & $34,19.8 \%$ \\
\hline $\begin{array}{l}\text { Stocking kits, taping tables, shelves, } \\
\text { etc. }\end{array}$ & $106,58.9 \%$ & $141,78.3 \%$ & $12,6.6 \%$ & $3,1.7 \%$ \\
\hline $\begin{array}{l}\text { Give a student-athlete over the } \\
\text { counter (OTC) medicine }\end{array}$ & $0,0 \%$ & $2,1.2 \%$ & $163,97.0 \%$ & $145,86.8 \%$ \\
\hline $\begin{array}{l}\text { Serve as "eyes and ears" at an } \\
\text { athletic event using a walkie-talkie } \\
\text { to communicate to the ATC located } \\
\text { at elsewhere }\end{array}$ & $52,30.2 \%$ & $45,25.7 \%$ & $91,52.9 \%$ & $70,40.0 \%$ \\
\hline File patient records & $29,17.0 \%$ & $77,44.0 \%$ & $89,52.1 \%$ & $22,12.6 \%$ \\
\hline $\begin{array}{l}\text { Perform e-stim or ultrasound on an } \\
\text { athlete }\end{array}$ & $0,0 \%$ & $15,8.8 \%$ & $141,82.9 \%$ & $11,6.5 \%$ \\
\hline $\begin{array}{l}\text { Perform wound care (bandages, } \\
\text { stopping blood, etc.) }\end{array}$ & $34,19.4 \%$ & $78,43.8 \%$ & $43,24.6 \%$ & $0,0 \%$ \\
\hline Stretching players & $26,14.8 \%$ & $85,46.7 \%$ & $46,26.1 \%$ & $0,0 \%$ \\
\hline $\begin{array}{l}\text { Talk to parents of an injured athlete } \\
\text { about their child's injury }\end{array}$ & $0,0 \%$ & $3,1.7 \%$ & $168,100 \%$ & $64,34.4 \%$ \\
\hline $\begin{array}{l}\text { Interpret referrals from other } \\
\text { healthcare providers }\end{array}$ & $0,0 \%$ & $4,2.4 \%$ & $167,99.4 \%$ & $\begin{array}{c}58, \\
34.1 \% \% \\
\end{array}$ \\
\hline Enforcing athlete sign-in procedures & $86,48.0 \%$ & $121,65.1 \%$ & $26,14.5 \%$ & $4,2.2 \%$ \\
\hline $\begin{array}{l}\text { Enter injury data into an EMR } \\
\text { system }\end{array}$ & $11,6.2 \%$ & $50,27.6 \%$ & $120,67.8 \%$ & $24,13.3 \%$ \\
\hline
\end{tabular}




\section{DISCUSSION}

In this exploratory study, we determined the task allowance and supervision of SAs and ATSs by SSATs. This area of research was identified as a need in the profession in 2002, specifically with ATSs completing clinical experiences in the secondary school setting. ${ }^{21}$ While ATSs are protected and regulated by the CAATE and athletic training programs, SSATs are permitting ATSs to complete more athletic training service tasks regardless of the risk of the activity as compared to SAs. As the profession has not recorded or tracked the number of SSATs integrating SAs into their clinical practice, this study helps to identify how prevalent this educational sector within athletic training is and frequency to which best practice recommendations are being followed during these clinical experiences.

\section{Terminology and General Descriptors}

Depending on the level of supervision and what tasks are permitted by the SSAT, the SA may be perceived as an extension of the SSAT to stakeholders in the community and the school. ${ }^{22}$ As such, there is a need to distinguish the SA from that of the ATS, as well as the SSAT. Although terminology does not change the acts of an individual, it does assist with the branding and marketing to external stakeholders, and ultimately, the vitality of the profession. The majority of participants in this study utilized the term "student athletic trainer," which should not be used to describe either a high school or a college student supervised by an athletic trainer. As a profession, we must begin to adhere to terminology changes that we have been discussing for over a decade. ${ }^{23}$

Additionally, it is vital that athletic trainers read and comprehend the state practice act from the regulatory agency that legally allows one to practice in that state whether it be licensure, certification, or registration. Previous research by Weidner, Noble, and Pipkin identified that over $21 \%$ of ATSs completing clinical education assignments in the college and university setting were unfamiliar with their state practice act regarding the limitations related to medical services being provided. ${ }^{24}$ The authors also suggested that violation of these state practices acts, even from the student perspective, detracts from our professional image and growth within the medical field. ${ }^{24}$ The rationale for this connection is the inclusion and unregulated task allowance of SAs in clinical practice is violation of many state practice acts including the states of South Carolina, Texas, Indiana, Ohio, Pennsylvania, and Virginia. 25-30 When exploring the state practice acts further, several regulatory documents are either using improper terminology or degree distinction to describe ATSs that should be able to practice as an exempt provider under the supervision of an athletic trainer. While CAATE provides standards related to supervision, some state practice acts expand on the proper supervision of ATSs as exempt providers such as the state of Ohio that states direct supervision as being in the "same location and available to immediately respond to the needs of the individual." Future efforts from the profession, specifically governmental affairs committees at the state, district, and national level, should seek to rectify terminology issues related to students involved with athletic training clinical practice in the state practice acts similar to the efforts by the state of Ohio. ${ }^{28}$

While SA programs expose numerous students to the profession of athletic training, the risks of having a minor diagnosing injuries/illnesses and making treatment, return to play, and intervention decisions are very high, specifically through the notion of negligent supervision. ${ }^{31}$ Additionally, it is important to reflect on the time necessary to supervise and monitor students during an athletic trainer's daily clinical practice. From our sample, SSATs stated they averaged $6 \pm 16$ SAs and $1 \pm 1$ ATS per day. While the profession has promoted the inclusion and expansion of SAs, it is important for SSATs to understand their limitations to provide direct supervision and mentoring. As the SSAT has been identified as the main socializing agent for college students pursuing athletic training, there is a need for the athletic trainer to understand the difference in anticipatory socialization for a SA and ATS ${ }^{32}$ Previous research identified that high school students can gain an introduction to the specialty of sports medicine which may influence future career decisions. ${ }^{32}$ Contrastingly, the long-hours and attitudes toward the day-to-day services can also be a detractor to the profession, specifically when the SSAT is attempting to replicate clinical education experiences of a professional athletic training program with that of the SA experiences of high school co-curricular activities. ${ }^{32}$ While the degree transition in athletic training education is seeking to expose undergraduate students to the graduate athletic training degree, previous research has proposed the potential need to accurately (i.e. - knowledge and skills) represent the profession during the high school experience as a potential recruiting mechanism. ${ }^{32} \mathrm{As}$ a profession, we must continue to explore the role of job shadowing and onthe-job learning by SAs through a formalized process following best practice standards set forth in the literature that are widely used in other healthcare professions. ${ }^{33,34}$ While formal coursework and formal clinical experiences are helpful to SAs, SSATs with teaching responsibilities should consider the use of career and technical education to ensure quality of curriculum and career pathways that accompany all before, during, or after school clinical experiences. ${ }^{35}$ 


\section{Training and Preparedness}

Professional athletic training programs must retain proper student records verifying several required trainings for the CAATE. ${ }^{14}$ As part of this verification process, a criminal background check, an annual blood-borne pathogen training, privacy training related to HIPAA and FERPA, and emergency cardiac care training are required of ATSs. ${ }^{14}$ These trainings are to ensure the student, as well as the public and patients, are protected. Contrastingly, most SAs do not have a formal curriculum that they follow, nor that SSATs have a formal regulatory body ensuring that best practice principles related to student and patient protection are adhered to. Our study provides evidence to suggest that all of the recommended training areas to prepare for clinical experiences were reported to be required by less than $50 \%$ of all SSATs integrating SAs into their athletic training facility. The American Heart Association states that they "[do] not mandate a minimum age requirement for learning CPR." As such, the ability for a SA or ATS become CPR certified should be something for the SSAT to consider as a training requirement, as the evidence supports that a child as young as 10 years old can learn and accurately complete the compressions associated with CPR. ${ }^{36}$

The recommended trainings are to ensure patient privacy and quality care. The importance of these trainings are multifaceted, including the general benefit to the American public if more individuals are trained in life saving skills such emergency cardiac care and blood-borne pathogen training. Additionally, quality care is essential specifically in acute, emergency situations. As emergency cardiac care is not a healthcare profession-specific skill, SAs and ATSs should both be able to assist the SSAT in the event of a student-athlete collapse. However, we identified that over half of SSATs report not including ATSs they supervise in their emergency action plans. The emergency team should be described and detailed regarding the roles of each member. Currently, recommendations for emergency action plans include members like coaches and athletic directors, yet the absence of ATSs in the document, who for face value has training and formal coursework related to emergency preparedness, is alarming, as these individuals are able to assist in a timely emergency response. We urge SSATs to consider updating their emergency preparedness documents to include ATSs involved in their clinical practice.

Future efforts related to training and preparedness should begin assessing the curriculum, whether formal or informal, that is provided by either the state, district, secondary school, or SSAT themselves related to sports medicine and athletic training classes for SAs. While this study did not explore the formal teaching processes for SAs, future investigations into the training and preparedness should explore what we are teaching a SA from the didactic and clinical perspectives, as well as begin to explore the role of a regulatory body to ensure SAs are protected and prepared through recommended trainings described in our results.

\section{Task Allowance}

The results of our study are indicative that SSATs are restrictive in nature to SAs and allowing more tasks to be completed by ATSs. We believe it is important to highlight that none of the SSATs that participated in this study were allowing autonomous SA clinical experiences related to performing a concussion evaluation, clearing an athlete to return to play, creating a rehabilitation program for an injured patient, talking to the parents of an injured athlete, or interpreting referrals. These findings are important to highlight as they are all categorized as high-risk activities in our study. While $100 \%$ compliance was not met, other high-risk activities were also not being permitted by the SSAT including $86 \%$ restricting the performance of orthopedic evaluations and $66 \%$ restricting the taping of an injured athlete's ankle. ATSs were also allowed to perform several of the skills in the task allowance instrument including $97 \%$ of SSATs allowing the taping of an injured athlete's ankle with either direct or indirect supervision, or autonomous practice. The task with the worst adherence to the guidelines for SAs is taping non-injured athletes with $61.7 \%$ allowing this to occur. The significance of this in clinical practice is that preventative techniques such as prophylactic taping are not as important as compared to other tasks in that a minor can complete this task. SSATs must be mindful that prevention is one of the domains of clinical practice and taping must be protected as a clinical task in the same manner as environmental monitoring, nutritional considerations, and policy development.

While return-to-play decisions are high-risk situations, they are still tasks that must be completed and practiced during clinical experiences for ATSs. In exploring case law, Rios vs Grossmont Union High School details several key factors to protect the student and patient during clinical experiences. In this case, a student was "volunteering" at the secondary school while completing his degree at an accredited professional athletic training program. During this clinical experience, the ATS was unsupervised, despite the secondary school having a certified athletic trainer on staff, during a football game in which a student-athlete sprained his ankle. ${ }^{22}$ The ATS subsequently evaluated, taped, functionally tested, and returned the patient to activity. ${ }^{1}$ On a subsequent play after returning to the game, the student-athlete was severely injured resulting in two fractured vertebrae and partial, temporary paralysis. ${ }^{22}$ The legal counsel attempted to link the lower extremity injury to the subsequent spinal cord injury through the notion of decreased balance and function predisposing the patient to the secondary situation. ${ }^{22}$ The jury found that the secondary school was not negligent in this case because of the lack of an established standard of care by the NATA regarding the management of ankle sprains, which interestingly was published months before in August 2013 in the form of a position statement. ${ }^{37}$ The Rios vs 
Grossmont Union High School case illustrates the increased risk to the supervising SSAT and the patient through unsupervised task allowance even despite the knowledge and skills that an ATS may have from a professional athletic training program.

While the current structure is mostly successful in preparing ATSs, novice athletic trainers and employers have identified the tasks associated with healthcare administration as deficient areas in the transition to practice. ${ }^{38,39}$ In our study, we identified that ATSs are not permitted to practice the skills of medical documentation, using patient management systems, and talking to parents of patients. Additionally, SSATs are not allowing the ATSs to make return-to-play decisions under their direct supervision. Walker, Thrasher, and Mazzerole discussed a similar finding that newly credentialed athletic trainers feel more prepared for the job during the transition to practice if they were are allowed to communicate with external stakeholders, make clinical decision, and manage a patient independently. ${ }^{40}$ If we combine these two findings together, the role of the SSAT as a preceptor is critical to the retention of ATSs in the profession specifically within the secondary school setting. When compared to ATSs, $68 \%$ of SSATs reported not permitting the SAs to complete administrative tasks related to patient records and medical documentation such as entering data into an electronic medical record. Filing patient records and medical documentation is an ill-defined situation within the best practice documents for SAs. We recommend that if a SA is allowed to complete these tasks, HIPAA and FERPA training is essential. Privacy concerns in the digital age are a growing issue in the healthcare industry due to the rise of social media and bait clicking. ${ }^{41,42}$ It is vital that we are teaching SAs and ATSs, currently reflected in the population as digital natives, the proper access to and dissemination of student health and educational records. ${ }^{43,44}$

One aspect of supervision throughout the state practice acts and CAATE standards is the idea of being able to intervene for the student and patient during the encounter. In our study, $50 \%$ of SSATs permitted an ATS to serve as the "eyes and ears" at an athletic event using a walkie-talkie to communicate to the certified athletic trainer located elsewhere. We identified similar results with $54 \%$ of SSATs allowing a SA to serve in the same capacity regardless of supervision status. Previous research identified that using walkie-talkie does not meet the CAATE standard for direct supervision. ${ }^{45}$ While the principle of direct supervision has been discussed throughout the athletic training literature as it relates to ATSs, our findings are comparable to previous research completed in 2006 regarding ATS in the college and university setting that identified that ATSs were not receiving the appropriate supervision by the preceptor. ${ }^{24,45-48}$

One interesting finding from our study was the limitation of both SAs and ATCs in dispensing over-the-counter medication. Additionally, we identified those SSATs that have both SAs and ATSs involved in their clinical practice both restricted the dispensing of over-the-counter medication and return-to-play decisions for both parties, but did allow the ATSs to perform both of these skills more frequently as compared to a SA. While we believe it is important to highlight the adherence to best practices for SAs, the ATSs may be involved in the conveyance of these medications to the patients. ${ }^{49}$ Although there are findings that display an issue within ATS task allowance, we believe it is important to also describe rationale behind this decision. Rather than the task allowance, the SSAT may have perceived this item from a different perspective. According the consensus statement, it is common practice to not provide over-the-counter medications to minors without previous parental consent. ${ }^{49}$ Therefore, the findings may not be accurate in stating that students cannot perform the skill of dispensing medication, but rather a limitation of the secondary school setting. 49 We believe it is also important to note that with only $27.3 \%$ of respondents reporting they supervised both SAs and ATSs, the confusion of each student groups' roles and task allowance may be a limited issue. With that in mind, the SSAT that have identified the distinction through the task allowance must continue to be an advocate for the profession through promotion of patient safety and the brand of athletic training as a vital member of the healthcare team, not simply a skill set that is equitable of an extracurricular high school program.

\section{Limitations and Future Direction}

This study is not without limitations. First, we explored the self-reported clinical experience task allowance from the SSATs perspective. Therefore, the results of this study can only describe what the SSAT believes they are allowing and limiting during the experiences. This lends to the idea that some clinical tasks may be performed by SAs and ATSs without the explicit grasp by the SSAT about what this looks like when placed as the "eyes and ears" at athletic events. Thus, it remains unclear what those duties look like outside of the supervised time, creating a conscious (knowledge of proper task allowance) incompetence (lack of implementation) from the lens of the SSAT. Many of the participants stated they had ATSs involved in their clinical practice, but the survey did not specifically acknowledge the progression of clinical experience supervision related to the knowledge and skills of the ATS. Therefore, future studies should attempt to provide a continuum of task allowance throughout the ATS educational progression to address when and why the SSAT may shift their supervision strategies. Specific questions in the survey addressed their teaching responsibilities and the role the SA had in the extracurricular activities, but did not address if the clinical experience were directed, monitored, or maintained by organizations such as HOSA-Future Health Professionals or The Association for Career and Technical Education. It is possible that the clinical experiences afforded by the SSAT may be supervised by an overarching body, rather than dictated by the SSAT themselves, and should be explored in future detail. 
Future directions related to this study should seek to identify the perceived and actual task performance of SAs and ATSs involved in clinical practice, specifically comparing secondary schools that incorporate both students in athletic training clinical experiences. Currently, we are unable to directly measure what the student is being allowed to complete. While the NATA provides guidelines, we as a profession assume that implementation is occurring because the documents are available. Future research should seek to understand the SSAT's perspective regarding what and why they allow a student to complete specific to the latitude of SAs compared to the restriction of ATSs from regulatory agencies. Finally, we must consider the current direction of the athletic training education during the degree elevation. The role of the SA has created a desire to seek a professional undergraduate athletic training program. With the change to the professional degree at the graduate level, we may see a similar elevation of interested individuals in the field of athletic training performing tasks, where previously this was SAs and could become student observers or interns that are non-matriculating athletic training students completing an undergraduate degree. Research should explore colleges and universities that have this dynamic to ensure roles and responsibilities amongst all members is understood by the public including internal and external stakeholders.

\section{CONCLUSION}

Most SAs are not prepared to enter the athletic training facility without the proper training including emergency cardiac care and first aid. Additionally, the terminology of SAs continues to be an issue for the profession. Overall, the SSATs are following most of the best practice guidelines related to the task allowance of SAs, while also allowing ATSs clinical experiences and patient encounters that will prepare them for future practice. However, a major area of concern is that these findings are not in $100 \%$ compliance with some CAATE standards and NATA supervision standards. As such, the proper supervision and task allowance of both ATS and SAs in the secondary school setting is simultaneously an education and clinical practice issue. The public image of the profession is at risk by having SAs complete the job-specific tasks of a healthcare provider, specifically an athletic trainer. Secondarily, the vitality of the profession is at risk if SSATs serving as preceptors are not exposing ATSs to key determinants related to the transition to practice while concurrently protecting the student and public through risk mitigation.

\section{REFERENCES}

1. Pike AM, Pryor RR, Vandermark LW, Mazerolle SM, Casa DJ. Athletic trainer services in public and private secondary schools. J Athl Train. 2017;52(1):5-11.

2. Pryor RR, Casa DJ, Vandermark LW, et al. Athletic training services in public secondary schools: a benchmark study. $J$ Athl Train. 2015;50(2):156-162.

3. Vandermark LW, Pryor RR, Pike AM, Mazerolle SM, Casa DJ. Medical care in the secondary school setting: Who is providing care in lieu of an athletic trainer? Athletic Training \& Sports Health Care. 2017;9(2):89-96.

4. Winkelmann ZK, Eberman LE. Characteristics of secondary school athletic trainers: Salary, job satisfaction, and perceived percentage of daily practice. Athletic Training \& Sports Health Care. 2017;9(3):124-132.

5. Guindon C, Eberman L, Winkelmann Z, Games K. Athletic trainers' injury prevention practice strategies and barriers in secondary schools. J Athl Train. 2017;52(6):S113.

6. Pike A, Pryor RR, Mazerolle SM, Stearns RL, Casa DJ. Athletic trainer services in US private secondary schools. J Athl Train. 2016;51(9):717-726.

7. Pitney WA, Mazerolle SM, Pagnotta KD. Work-family conflict among athletic trainers in the secondary school setting. $J$ Athl Train. 2011;46(2):185-193.

8. Wham Jr GS, Saunders R, Mensch J. Key factors for providing appropriate medical care in secondary school athletics: athletic training services and budget. J Athl Train. 2010;45(1):75-86.

9. Pitney WA. A qualitative examination of professional role commitment among athletic trainers working in the secondary school setting. J Athl Train. 2010;45(2):198-204.

10. Pitney WA, Stuart ME, Parker J. Role strain among dual position physical educators and athletic trainers working in the high school setting. Physical Educator. 2008;65(3):157.

11. McLeod TCV, Bliven KCH, Lam KC, Bay RC, Valier ARS, Parsons JT. The national sports safety in secondary schools benchmark (N4SB) study: defining athletic training practice characteristics. J Athl Train. 2013;48(4):483-492.

12. Corsi-Bunker A. Guide to the education system in the United States. University of Minnesota, nd Web. 2015;23.

13. National Athletic Trainers' Association. Official statement on proper supervision of secondary school student aides 2014; http://www.nata.org/sites/default/files/student-aide-statement.pdf. Accessed July 26, 2017.

14. Comission on Accreditation of Athletic Training Education. CAATE 2020 Standards for Accreditation of Professional Athletic Training Programs. 2018; https://caate.net/wp-content/uploads/2018/02/2020-Standards-for-ProfessionalPrograms-copyedited-clean.pdf. Accessed August 24, 2018. 
15. National Athletic Trainers' Association. Secondary School Student Aide Q\&A. 2015; https://www.nata.org/professionalinterests/job-settings/secondary-school/resources/student-aid-faq. Accessed July 26, 2017.

16. Cooper L, Thornton J. Student Aide Letter. 2014; https://www.nata.org/sites/default/files/student-aide-letter.pdf. Accessed July 26, 2017.

17. Commission on Accreditation of Athletic Training Education. Standards for the academic accreditation of professional athletic training programs. Commission on Accreditation of Athletic Training Education; Round Rock, TX; 2012.

18. $\quad$ NATA ATLAS. 2018; https://ksi.uconn.edu/nata-atlas/, Accessed September 14, 2018.

19. Bosnjak M, Tuten TL. Classifying response behaviors in web-based surveys. J Comput Mediat Commun. 2001;6(3):JCMC636.

20. Burton LJ, Mazerolle SM. Survey instrument validity part I: Principles of survey instrument development and validation in athletic training education research. Athl Train Educ J. 2011;6(1):27-35.

21. Weidner TG, Pipkin J. Clinical supervision of athletic training students at colleges and universities needs improvement. J Athl Train. 2002;37(4 suppl):S-241.

22. Rios v. Grossmont Union High School Dist, (Cal: Court of Appeal, 4th Appellate Dist., 1st Div. 2013).

23. Davis C, Misasi S. Student athletic trainer vs. athletic training student: get over it and get on with it. NATA News. 2001;16.

24. Weidner TG, Noble GL, Pipkin JB. Athletic training students in the college/university setting and the scope of clinical education. J Athl Train. 2006;41(4):422.

25. South Carolina Code of Laws. Title 44, Chapter 75 - Athletic Trainers' Act of South Carolina.

26. Administrative Rules of the Texas Department of Licensing and Regulation. 16 Texas Administrative Code, Chapter 110. 2018.

27. Indiana Athletic Trainers Board. Title 898. 2018.

28. Ohio Occupational Therapy PT, and Athletic Trainers Board, . Laws and Rules Regulating the Practice of Athletic Training 2018.

29. Pennsylvania Medical Practice Act of 1985. Subchapter H - Athletic Trainers.

30. Virginia Board of Medicine. Regulations governing the licensure of athletic trainers. 2017.

31. Falender CA, Shafranske EP. Casebook for clinical supervision: A competency-based approach. American Psychological Association; 2008.

32. Mensch J, Mitchell M. Choosing a career in athletic training: exploring the perceptions of potential recruits. J Athl Train. 2008;43(1):70-79.

33. Perkins T. Introduction to healthcare careers through hospital-based tours. Nurs Manag. 2018;49(8):9-10.

34. Morrell BL, Detty-Gin J. Bringing clarity to job shadowing. Nurs Manag. 2016;47(4):42-50.

35. Stone III JR. Introduction to pathways to a productive adulthood: the role of CTE in the American high school. Taylor \& Francis; 2017.

36. Roppolo LP, Pepe PE. Retention, retention, retention: targeting the young in CPR skills training! Critical Care. 2009;13(5):185.

37. Kaminski TW, Hertel J, Amendola N, et al. National Athletic Trainers' Association position statement: conservative management and prevention of ankle sprains in athletes. J Athl Train. 2013;48(4):528-545.

38. Carr WD, Volberding J. Employer and employee opinions of thematic deficiencies in new athletic training graduates. Athl Train Educ J. 2012;7(2):53-59.

39. Mazerolle SM, Whitney M, Eason C. Examining the experiences of athletic trainers as they transition into their first fulltime position. Journal of Sports Medicine and Allied Health Sciences: Official Journal of the Ohio Athletic Trainers Association. 2017;2(3):2.

40. Walker SE, Thrasher AB, Mazerolle SM. Exploring the perceptions of newly credentialed athletic trainers as they transition to practice. J Athl Train. 2016;51(8):601-612.

41. Smailhodzic E, Hooijsma W, Boonstra A, Langley DJ. Social media use in healthcare: a systematic review of effects on patients and on their relationship with healthcare professionals. BMC Health Serv Res. 2016;16(1):442.

42. Neil ER, Winkelmann ZK, Eberman LE. Athletic trainers' knowledge of legal practice within information technology and social media. Journal of Sports Medicine and Allied Health Sciences: Official Journal of the Ohio Athletic Trainers Association. 2017;3(2):1.

43. Bennett S, Maton K, Kervin L. The 'digital natives' debate: A critical review of the evidence. Br J Educ Technol. 2008;39(5):775-786.

44. Winkelmann ZK, Neil ER, Eberman LE. Athletic training students' knowledge of ethical and legal practice with technology and social media. Athl Train Educ J. 2018;13(1):3-11.

45. Sexton P, Levy LS, Willeford KS, et al. Supervised autonomy. Athl Train Educ J. 2009;4(1):14-18. 
46. Mazerolle SM, Bowman TG. A time for reflection: Should we reconsider the direct supervision standard in clinical education? Athl Train Educ J. 2017;12(2):106-112.

47. Scriber $\mathrm{K}$, Trowbridge $\mathrm{C}$. Is direct supervision in clinical education for athletic training students always necessary to enhance student learning? Athl Train Educ J. 2009;4(1):32-37.

48. Levy LS, Gardner G, Barnum MG, et al. Situational supervision for athletic training clinical education. Athl Train Educ J. 2009;4(1):19-22.

49. National Athletic Trainers' Association. Consensus statement: Managing prescription and non-prescription medication in the athletic training facility. NATA News. January 2009:14-16. 